\title{
Old drug, new tricks: haloperidol inhibits secretion of proinflammatory cytokines
}

\author{
R J Moots, Z Al-Saffar, D Hutchinson, S P Golding, S P Young, P A Bacon, \\ P J McLaughlin
}

\begin{abstract}
Objectives-It was noted that treatment of a patient with acute mania by haloperidol was associated with marked improvement in activity of rheumatoid arthritis. The objective of this study was to examine the effects of haloperidol on inflammatory cytokine release in vitro, as a potential mechanism to explain the in vivo antiinflammatory effects of haloperidol.

Methods-The effect of haloperidol on the production of inflammatory cytokines interleukin $1 \beta$ (IL1ß) and tumour necrosis factor $\alpha(T N F \alpha)$ was measured in bacterial lipopolysaccharide stimulated whole blood cultures and on the promonocyte cell line THP-1, using commercial and in house enzyme linked immunosorbent assays to measure cytokine concentrations.

Results-Haloperidol inhibited lipopolysaccharide stimulated production of both IL1 $\beta$ and TNF $\alpha$ in vitro in a dose dependent manner and over a prolonged time period. Marked inhibition was seen over a range of concentrations of haloperidol from $0.5 \mu \mathrm{g} / \mathrm{ml}$ to $50 \mu \mathrm{g} / \mathrm{ml}$, including those predicted to occur in the patient's blood.

Conclusions-Haloperidol treatmentseemed to alleviate inflammation in rheumatoid arthritis. In vitro experiments would suggest that the mechanism is by direct inhibition of proinflammatory cytokine release. This phenomenon requires further investigation and may potentially lead to the development of novel treatment. (Ann Rheum Dis 1999;58:585-587)
\end{abstract}

( University Hospital Aintree, Longmoor Lane, Liverpool

L9 7AL

R J Moots

Z Al-Saffar

D Hutchinson

Department of Rheumatology, Birmingham

University,

Birmingham

S P Golding

$S$ P Young

P A Bacon

Department of Immunology,

University of

Liverpool, Liverpool

P J McLaughlin

Correspondence to:

Dr R J Moots.

Accepted for publication 24 March 1999.
A 32 year old woman with stable seropositive RA controlled by non-steroidal anti-inflammatory drugs (NSAIDs) was admitted with acute mania. She was coincidentally noted to have extensive active synovitis involving the small joints of the hands and feet, together with knees and wrists, and early morning stiffness lasting until the evening. Markers of inflammation in the blood were raised with an erythrocyte sedimentation rate (ESR) of $65 \mathrm{~mm} 1 \mathrm{st}$ $\mathrm{h}$ and $\mathrm{C}$ reactive protein (CRP) $90 \mathrm{mg} / \mathrm{dl}$. These clinical and laboratory features remained after two days of observation, and continued administration of NSAID. Oral haloperidol at a dose of $5 \mathrm{mg}$ twice a day was then started to control the mania. Over the next two days not only did her mood normalise, but also the synovitis markedly resolved in her hands, wrists and knees. The CRP dropped in parallel to $20 \mathrm{mg} / \mathrm{ml}$. During this time, the patient noticed that her early morning stiffness was limited to only approximately 90 minutes.

Haloperidol was gradually stopped over the next week. The patient remained fully ambulant and active throughout, and there was no other change in treatment. Two days after stopping haloperidol she suffered a marked flare of synovitis affecting the same joints as before, and complained of fatigue, with a parallel rise in CRP to $80 \mathrm{mg} / \mathrm{ml}$ and early morning stiffness of approximately six hours. Her mood remained normal and she was no more active around the ward than before. The flare was managed by intra-articular corticosteroid injections. She was discharged home prescibed sulfasalazine and has remained well.

\section{Methods}

The potential effect of haloperidol (stock solution $5 \mathrm{mg} / \mathrm{ml}$ for injection: Janssen Pharmaceuticals Ltd) on proinflammatory cytokines IL1 $\beta$ and TNF $\alpha$ production by whole blood on stimulation with bacterial lipopolysaccharide (LPS) was investigated using commercial ELISAs.

The method was adapted from that described by Van Wauwe et al. ${ }^{3}$ Briefly, peripheral blood was collected from a healthy male donor into heparin tubes $(12.5 \mathrm{u}$ heparin/ml). It was diluted in RPMI 1640 medium and aliquoted into $250 \mu 1$ fractions in 24 well Nunclon multidish plates containing bacterial LPS $(E$ coli 0111: B4, Difco) at a final concentration of $80 \mu \mathrm{g} / \mathrm{ml}$, together with haloperidol at final concentrations of $0.5 \mu \mathrm{g} / \mathrm{ml}, 5 \mu \mathrm{g} / \mathrm{ml}$, or 50 $\mu \mathrm{g} / \mathrm{ml}$. At various time points (6 hours, 24 hours, 48 hours, and 72 hours) cell free supernatants were collected by two times centrifugation of whole blood cultures at $2000 \mathrm{~g}$ for five minutes. These were stored at $-20^{\circ} \mathrm{C}$ for up to three days before assay for $\mathrm{TNF} \alpha$ and IL $1 \beta$. 

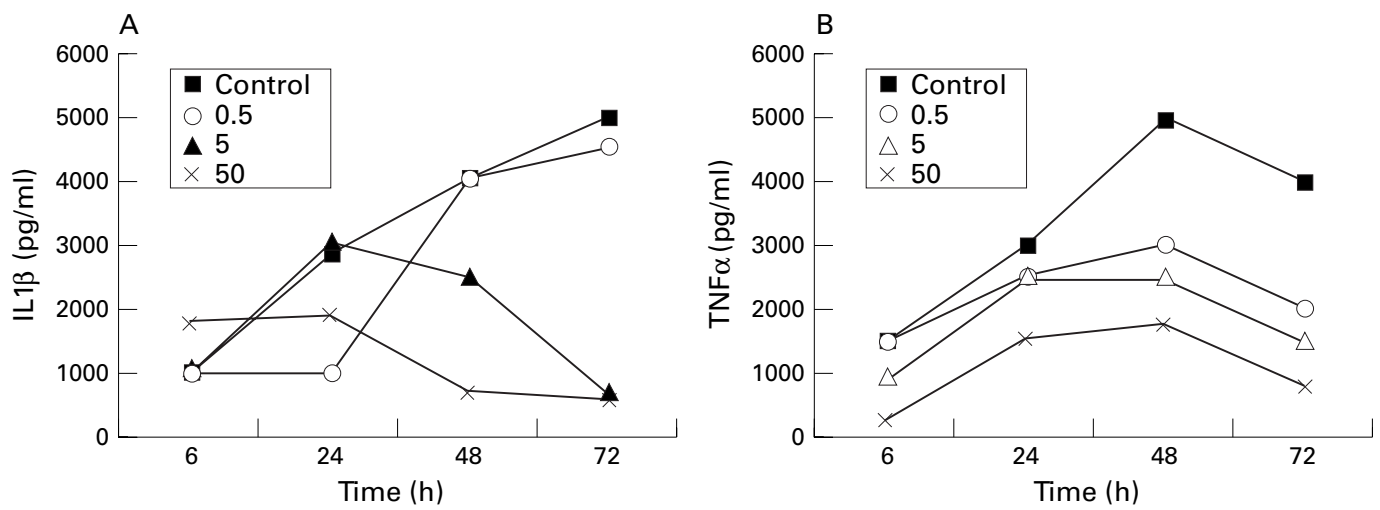

Figure 1 Inhibition of release of inflammatory cytokines (A) IL1B and (B) TNFa by haloperidol at concentrations from $50 \mu \mathrm{g} / \mathrm{ml}$ down to $0.5 \mu \mathrm{g} / \mathrm{ml}$, compared with medium control: LPS stimulated whole blood.

The Genzyme human TNF $\alpha$ duo set and $\mathrm{R}+\mathrm{D}$ systems IL $1 \beta$ matched pair ELISA kits were used to measure relevant cytokines. Both kits involve antigen capture with monoclonal antibody, addition of biotinylated second layer antibody and visualisation with horseradish peroxidase/peroxidase substrate in an optical plate reader. Each ELISA measurement was performed in triplicate wells. An in house ELISA $^{4}$ was also used in parallel to estimate IL1 $\beta$ production from an unstimulated promonocyte cell line THP-1. In this case, an additional drug with effects on the central nervous system, diazepam, was studied in parallel as control. Measurements were again performed in triplicate wells.

\section{Results}

Haloperidol suppressed production of both IL1 $\beta$ and TNF $\alpha$ from bacterial LPS stimulated whole blood over a wide range of concentrations, including those predicted pharmacologically (fig 1). These observation were consistent over prolonged time periods (fig 1) and with other concentrations of haloperidol over the same time periods (data not shown). In addition, haloperidol and not the control diazepam similarly suppressed unstimulated IL1 $\beta$ production from THP-1 cells using the in house IL1 $\beta$ ELISA (fig 2). The potential effects of haloperidol on cell

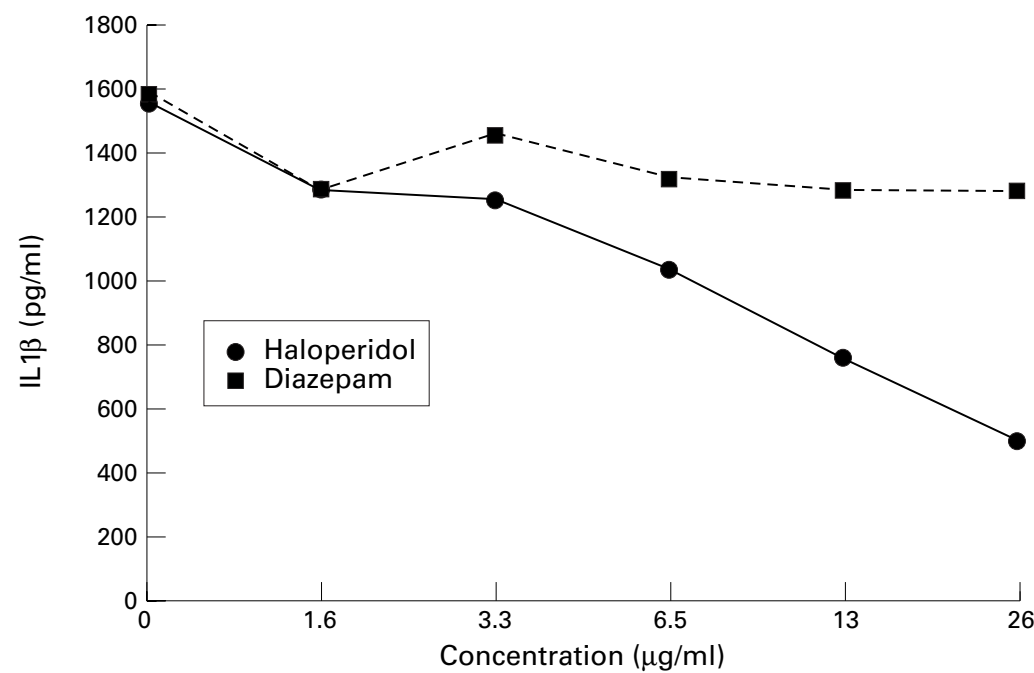

Figure 2 Production of IL1 $\beta$ by the human promonocytic cell line THP-1 was determined in the presence of varying concentrations of haloperidol, and as control, diazepam. viability, assessed by trypan blue exclusion, and general morphology by light microscopy, were also studied. Both of these features were unaffected by addition of haloperidol over the same range of concentrations. A ${ }^{3} \mathrm{H}$-leucine uptake assay, to measure total protein synthesis of proliferating cells, was performed in the presence of haloperidol at a concentration of $0.5 \mathrm{mg} / \mathrm{ml}$ (data not shown). Again, there was no effect on total protein synthesis.

\section{Discussion}

Haloperidol has been reported to chronically suppress inflammatory arthritis. In a small trial using technetium scans as a marker of joint inflammation, it was observed that there was a reduction of isotope uptake of technetium in patients taking similar doses to that described in this report. The mechanism was unknown. ${ }^{5}$ Similar, less dramatic observations have been associated with chlorpromazine-of different chemical structure and class to haloperidol. Chlorpromazine is known to inhibit secretion of some cytokines. ${ }^{6-8}$ Our data indicate that haloperidol inhibits release of both proinflammatory IL $1 \beta$ and $\mathrm{TNF} \alpha$, potentially explaining the striking clinical improvement observed in our patient. The short time interval (up to six hours) before effect on $\mathrm{TNF} \alpha$ suggests that haloperidol may have an inhibitory effect on release. The later effects (about 48 hours) on IL1 $\beta$ production implies that inhibition of this cytokine may be modulated at the gene level. In a recent study of psychotic patients taking major anti-psychotic drugs it was observed that withdrawal of haloperidol was associated with an increase in cerebrospinal fluid IL1 $\beta$ concentration, but without a clinical change. ${ }^{9}$ New generations of agents that directly interfere with cytokine secretion, perhaps binding to the same receptors on lymphocytes as haloperidol, may play a key part in the management of inflammatory joint disease.

1 Arend WP, Dayer JM. Inhibition of the production and effects of interleukin-1 and tumor necrosis factor alpha in rheumatoid arthritis. Arthritis Rheum alpha in

2 Elliott MJ, Maini RN, Feldmann M, Kalden JR, Antoni C, Smolen JS, et al. Randomised double-blind comparison of chimeric monoclonal antibody to tumour necrosis factor chimeric monoclonal antibody to tumour necrosis factor
alpha (cA2) versus placebo in rheumatoid arthritis. Lancet 1994;344:1105-10 
3 Van Wauwe J, Aerts F, Van Genechten H, Bollcx H, Deleersnijer W, Walter $\mathrm{H}$. The inhibitory effect of pentamidine on the production of chemotactic cytokines by in vitro stimulated human blood cells. Inflamm Res 1996;45:357-63.

4 Golding S, Emery P, Young SP. Tenidapmodulated proinflammatory cytokine activation of a monocyte cell line. J Immunol 1995;154:5384-90.

5 Grimaldi MG. Serum sulfhydryl levels in rheumatoid patients treated with haloperidol. Scand I Rheumatol 1980;9:225-8.

6 Zinetti M, Galli G, Demitri MT, Fantuzzi G, Minto M, Ghezzi $\mathrm{P}$, et al. Chlorpromazine inhibits tumour necrosis factor synthesis and cytotoxicity in vitro. Immunology 1995;86:416-21.
7 Mengozzi M, Fantuzzi G, Faggioni R, Marchant A, Goldman M, Orencole S, et al. Chlorpromazine specifically inhibits peripheral and brain TNF production, and up-regulates IL-10 production, in mice. Immunology 1994;82:207-10.

8 Bertini R, Garattini S, Delgado R, Ghezzi P. Pharmacological activities of chlorpromazine involved in the inhibition of tumour necrosis factor production in vivo in mice. Immunology 1993;79:217-19

9 McAllister CG, van KD, Reln TJ, et al. Increases in CSF levels of interleukin-2 in schizophrenia: effects of recurrence of psychosis and medication status. Am J Psychiatry 1995;152:1291-7. 